\title{
Omega-3 Supplementation and its Effect on Lipid Profile in Intrauterine Growth Restriction (IUGR) Neonates
}

\author{
ANWAAR R.A. EL-ALKAMY, M.Sc.*; MOHAMED A. ROWISHA, M.D.*; HEBA S. EL-MAHDY, M.D.* and \\ HEMMAT E. EL-HORANY, M.D.** \\ The Departments of Pediatrics Medicine* and Medical Biochemistry**, Faculty of Medicine, Tanta University, Egypt
}

\begin{abstract}
Background: IUGR is an important cause of perinatal morbidity and mortality. It is noted to affect approximately $5-15 \%$ of pregnant women. Omega-3 fatty acids are considered essential fatty acids. They are necessary for human health, but the body can't make them. They play a crucial role in brain function, as well as normal growth and development.
\end{abstract}

Aim of Study: Was to investigate the serum lipid profile level in full term neonates with IUGR and the effect of Omega3 supplementation on its level.

Subjects and Methods: This prospective clinical trial was carried out at Neonatal Intensive Care Unit (NICU), Tanta University Hospital, over one year between April (2015) to May (2016). It was conducted on 50 full term IUGR neonates. Twenty five of them received Omega 3 supplementation as study group compared to 25 full term IUGR neonates without any supplementation enrolled as a control group. They were subjected to full history taking $\&$ thorough clinical examination, and they were investigated for estimation of complete blood picture, C-reactive protein, serum Urea and Creatinine, serum electrolytes $\left(\mathrm{Na}^{+}, \mathrm{K}^{+}, \mathrm{Ca}\right)$ and Specific Laboratory investigations: (Total Serum Cholesterol, Serum Triglycerides, HDL-Cholesterol, LDL-Cholesterol and VLDL-Cholesterol).

Results: There was significant increase in level of LDL in cases and control groups. There was significant decrease of LDL after 1 week in cases group more than control group. As regard rate of decrement of high levels of LDL there was significant decrement rate after 2 weeks of supplementation with Omega 3 by $55.84 \%$ in cases group which was more than the decrement in control group which was $31.34 \%$. Also, there was an increase in level of TC initially in IUGR neonates and this level was decreased after supplementation of Omega 3 for 2 weeks. There was a decrease in level of HDL initially in IUGR neonates and this level was significantly increased after supplementation of Omega 3 for 2 weeks. There was an increase in level of TG initially in IUGR neonates and this level was decreased after supplementation of Omega 3 for 2 weeks. There was an increase in level of VLDL initially in

Correspondence to: Dr. Anwaar R.A. El-Alkamy, The Department of Pediatric Medicine, Faculty of Medicine, Tanta University, Egypt
IUGR neonates and this level was significantly decreased after supplementation of Omega 3 for 2 weeks.

Conclusion: Screening for lipid profile is important to be done in all IUGR neonates at birth and during follow-up. Long term follow-up is recommended for all IUGR neonates for detection of CVD and the effect of Omega 3 on these groups.

Key Words: Omega 3 - IUGR - Neonatology.

\section{Introduction}

INTRAUTERINE Growth Restriction (IUGR) refers to a condition in which a fetus is unable to achieve its genetically determined potential size. This functional definition seeks to identify a population of fetuses at risk for modifiable but otherwise poor outcomes. This definition intentionally excludes fetuses that are Small for Gestational Age (SGA) but are not pathologically small [1] .

In accurately dated pregnancies, approximately $80-85 \%$ of fetuses identified as being IUGR are constitutionally small but healthy, $10-15 \%$ are 'true' IUGR cases, and the remaining $5-10 \%$ of fetuses are affected by chromosomal/structural anomalies or chronic intrauterine infections, so IUGR is an important cause of perinatal morbidity and mortality [2]. Egypt has one of the highest incidences of IUGR. There is an alarming high level of heavy metals toxicity in Egypt that was positively correlated to IUGR. Increased placental apoptosis may be one of the possible mechanisms behind the effect [3]

Maternal obesity may be associated with metabolic factors that affect the intrauterine environment, fetal growth, and the offspring's long-term risk for chronic disease [4]. During the third trimes- 
ter of pregnancy, fetuses require approximately 40 to $60 \mathrm{mg}$ of n-3 LCPUFAs (long chain polyunsaturated fatty acids) per kilogram of body weight per day. During the last gestational trimester and first postnatal months, there is significant growth of the human brain and a large increase in cerebral volume of DHA and AA [ $\mathbf{r}$. The major effects of higher levels of Omega-3 polyunsaturated fatty acids (n-3 LCPUFAs) during pregnancy are associated with the development of brain and nerve tissues during the period of maximum intrauterine accretion [6]

\section{Patients and Methods}

This case control study was carried out over one year between April (2015) to May (2016) at NICUs of Pediatric Department, Tanta University Hospital after taking paternal consent. It was approved by the Ethical Committee of the Faculty of Medicine, Tanta University.

A total of 50 full term IUGR neonates were included in this study and were categorized into 2 groups: Group I: 25 full term IUGR neonates who received Omega-3 supplement (Docosa-hexa-enoic acid (DHA $40 \mathrm{mg} / \mathrm{kg} /$ day), after establishment of full feeding. Group II: 25 full term IUGR neonates who were followed-up to full feeding without receiving any supplementation. Preterm neonates or those who had multiple congenital anomalies including GIT anomalies, congenital infection or Cholestasis were excluded.

\section{All neonates in both groups were subjected to:}

A- Complete history taking especially for history of maternal age, mode of delivery, maternal dietary intake of Omega-3 during pregnancy \& history of maternal infection (timing of rupture of membranes, history of TORCH screening) or maternal diseases such as hypertension (preeclampsia if present), diabetes mellitus, anemia and any placental disorders such as placenta previa or placental insufficiency.

B- Full clinical examination: (Gestational age assessment by New Ballard Score) [7]. Vital signs (pulse, temperature, respiratory rate, blood pressure).

C- Anthropometric measures (weight, length, head circumference) at birth, after the case reach to full feeding and after 2 weeks from Omega 3 supplementation to IUGR neonates. Measurement was done in both study groups. Weight was measured by using electronic scale and length was measured by using body-length measurer by NICU nurse.
D- All cases were followed as regard establishment of full feeding; follow-up of weight gain, length, H.C, P.I, development of sepsis and development of feeding intolerance or Necrotizing Enterocolitis (NEC).

E- Intervention: The case group was given Omega 3 in a dose of $40 \mathrm{mg} / \mathrm{kg} /$ day [8], after establishment of full-feeding and for 2 weeks duration. We used Omega-300 (Montana pharmaceutical industry) capsule which contains $1000 \mathrm{mg}$ Omega 3 fatty acids. Mothers were learned how to use the capsule after we calculated the suitable dose for her baby. The contents of the capsule were taken by a syringe and mother dissolve it in $10 \mathrm{ml}$ of expressed breast milk or freshly prepared formula and then shaking it very well, then gave the baby the calculated dose once daily for two weeks.

\section{Blood sampling:}

- Timing of Blood sampling: Blood sampling was obtained from all neonates at birth, after establishment of full feeding and 2 weeks after Omega 3 supplementation for measuring lipid profile. These samples were obtained before breast feeding and at least $2 \mathrm{~h}$ after the previous feed between 8 and $10 \mathrm{am}$ to be done in fasting blood specimen. This may hold true due to two main reasons:

A- Post prandial triglycerides remain elevated for several hours.

B- Most reference values for serum lipids are established on fasting blood specimen. National Cholesterol Education Program (NCEP) and European guidelines also recommend doing lipid profile in fasting blood specimen for assessment of cardiovascular risk [9]

- Sampling: Four ml venous blood samples were collected from each baby into disposable plastic tubes and allowed to clot then centrifuged at $3000 \mathrm{rpm}$ for 10 minutes to separate the serum. The obtained sera were stored in aliquots at $-80^{\circ} \mathrm{C}$ till used for different estimations. Initially the $4 \mathrm{ml}$ were divided into 3 tubes. One $\mathrm{ml}$ for $\mathrm{CBC}, 1.5 \mathrm{ml}$ for lipid profile and $1.5 \mathrm{ml}$ for the rest of investigations (CRP, Na, K, Ca, BUN, Cr). The second sample was used for lipid profile only. The third sample was for lipid profile and CRP.

- Some precautions during sampling: In addition to fasting/non-fasting state there are other factors (pre-analytical) which may affect lipid components: A- A change from an upright to a supine position due to dilutional effect can reduce the cholesterol levels by $10 \%$ and triglycerides by $12 \%$. 
B- Prolonged tourniquet application (2-5min) can increase cholesterol from 5 to $15 \%$.

$\mathrm{C}$ - Cholesterol is slightly higher in winter than in summer and the opposite is true for triglycerides [10]. Blood collection and serum separation were done under complete aseptic condition. All the blood samplings and all needles used were disposed according to the standard protocols of infection control policy.

All patients and controls were subjected to the following investigations:

1- Estimation of complete blood picture (Hemoglobin $(\mathrm{Hb} \%)$, Hematocrite value, Platelets count and Total leucocytic count) by Coulter T660.

2- Estimation of C-reactive protein by Latex agglutination method (BioMED).

3- Estimation of serum Urea and Creatinine: AUTOMATED TC-MATRIX CHEMISTRY ANALYZER (USA), based on Colorimetric-kinetic modified jaffe's method.

4- Estimation of serum electrolytes $(\mathrm{Na}, \mathrm{K}, \mathrm{Ca})$ : By Spectro-photometer RA50 based on Colorimetric method.

5- Specific laboratory investigations: Estimation of Total Serum Cholesterol, Serum Triglycerides and HDL-Cholesterol were determined by AUTOMATED TC-MATRIX CHEMISTRY ANALYZER (USA) based on Colorimetric method. While LDL-Cholesterol was determined by using Friedwald's formula [11]: LDL-C = Total Cholesterol (Triglycerides/5 + HDL Cholesterol).

\section{Statistical analysis:}

In addition to the descriptive data, statistical analysis was done using IBM SPSS Statistc Version 20 Program. Data were expressed as mean \pm SD and analyzed using the Chi square $\left(\chi^{2}\right)$ test and the student's $t$-test to assess the significance of difference in the levels between different parameters. $p<0.05$ was accepted as significant. Coefficient $(r)$ of two variables was also done by using Pearson correlation coefficient $(r)$ with $p$-value calculation.

\section{Results}

Laboratory assessments of the measured parameters in the different submitted groups are presented in the following tables and figures:
Table (1): Comparison between the two studied groups as regard to demographic data.

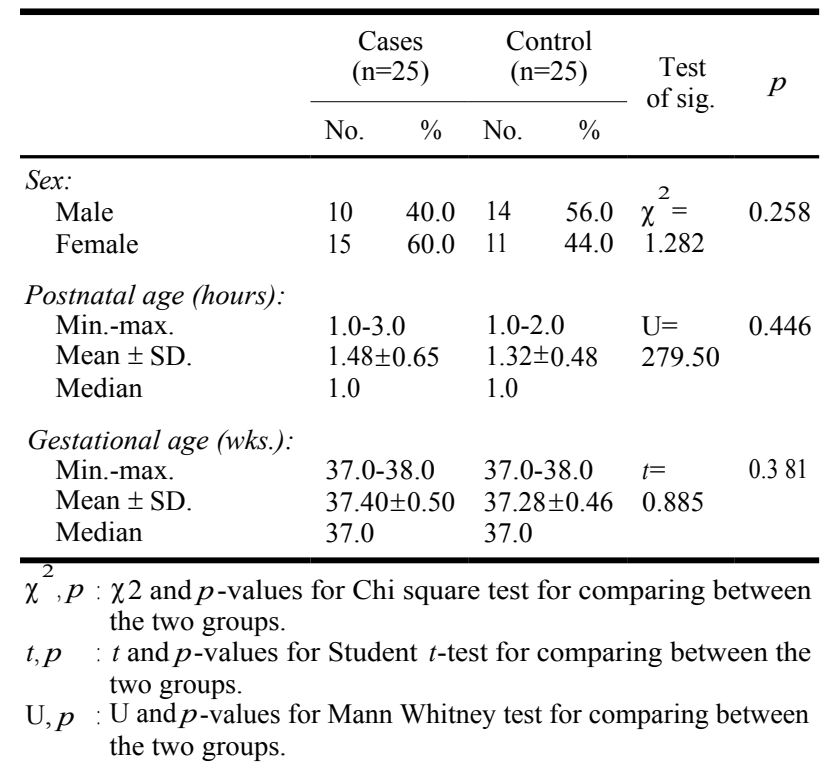

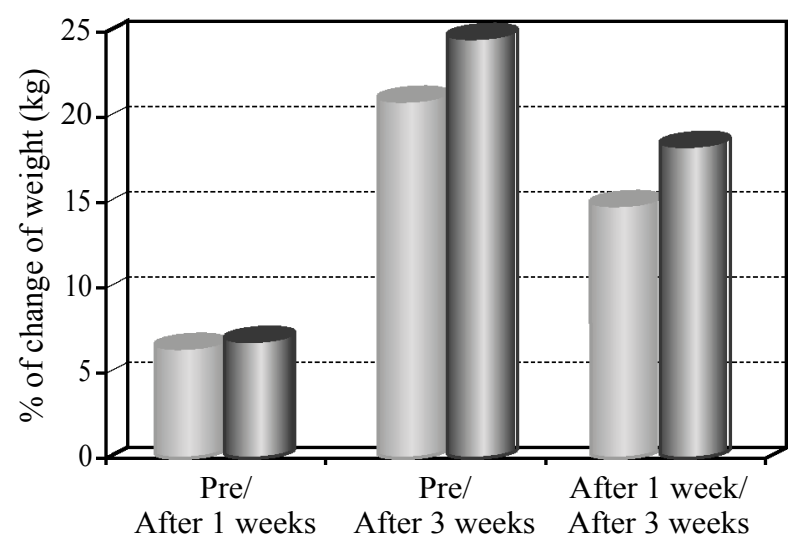

Cases

Control

Fig. (1): Comparison between changes in birth weight before and after the therapy in both groups.

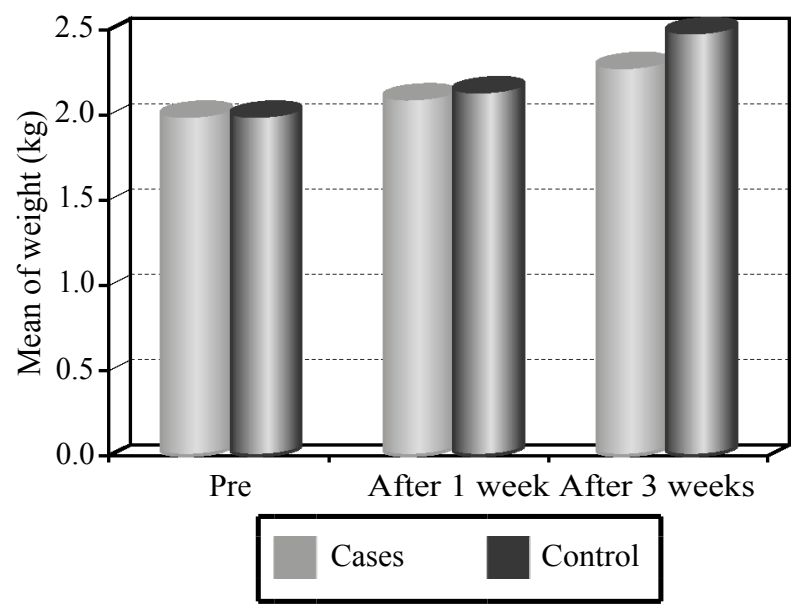

Fig. (2): Comparison between the different studied periods as regard to weight $(\mathrm{kg})$ in each group. 


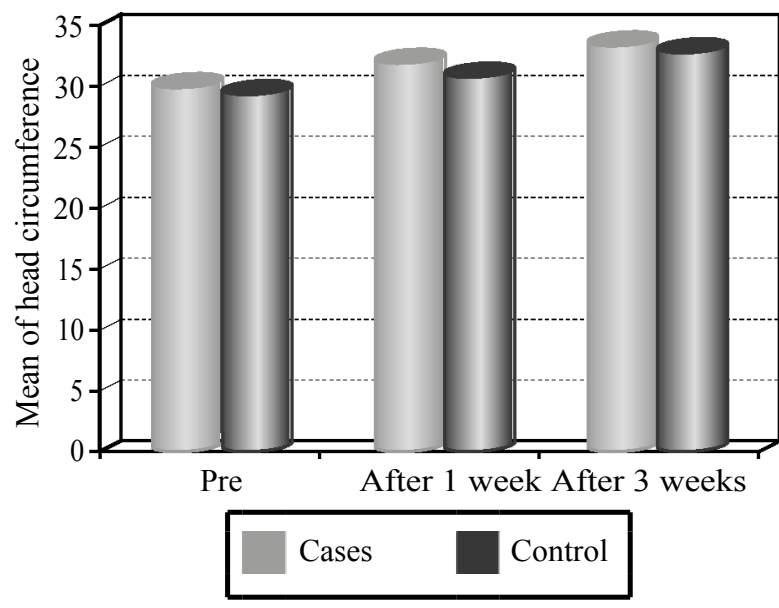

Fig. (3): Comparison between the different studied periods as regard to Head Circumference (HC) in each group.

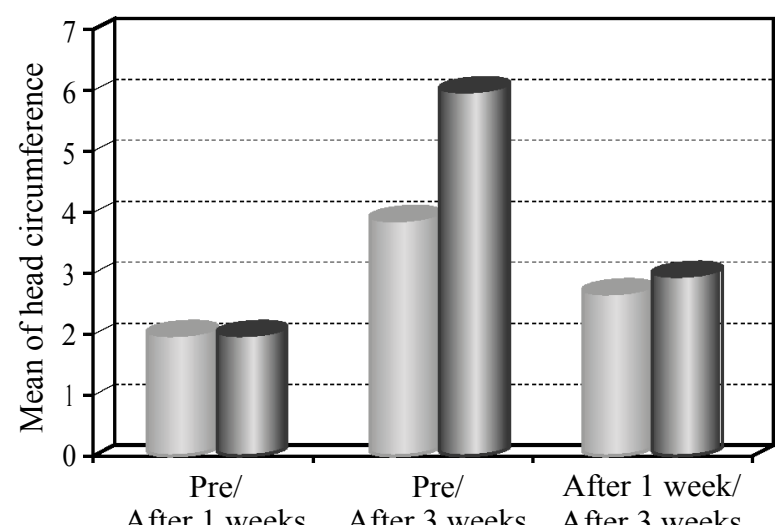

After 1 weeks After 3 weeks After 3 weeks

$$
\text { Cases Control }
$$

Fig. (4): Comparison between change in H.C before and after therapy in both studied groups.

Table (2): Comparison between the two studied groups as regard mode of delivery, antenatal risk factors and maternal Omega 3 intake.

\begin{tabular}{|c|c|c|c|c|c|c|}
\hline & \multicolumn{2}{|c|}{$\begin{array}{l}\text { Cases } \\
(\mathrm{n}=25)\end{array}$} & \multicolumn{2}{|c|}{$\begin{array}{l}\text { Control } \\
(\mathrm{n}=25)\end{array}$} & \multirow[t]{2}{*}{$x^{2}$} & \multirow[t]{2}{*}{$p$} \\
\hline & No. & $\%$ & No. & $\%$ & & \\
\hline \multicolumn{7}{|l|}{ Mode of delivery: } \\
\hline Normal vaginal & 6 & 24.0 & 6 & 24.0 & 0.000 & 1.000 \\
\hline Cesarean section & 19 & 76.0 & 19 & 76.0 & & \\
\hline \multicolumn{7}{|l|}{ Antenatal risk factor: } \\
\hline No risks & 13 & 52.0 & 13 & 52.0 & 0.000 & 1.000 \\
\hline Anemia & 6 & 24.0 & 1 & 0.0 & 0.041 & 0.09 \\
\hline HTN & 6 & 24.0 & 11 & 44.0 & 0.08 & 0.156 \\
\hline D.M & 0 & 0.0 & 0 & 0.0 & & \\
\hline D.M + HTN & 0 & 0.0 & 0 & 0.0 & & \\
\hline Anemia + D.M + HTN & 1 & 0.0 & 1 & 4.0 & 0.5 & 1.000 \\
\hline \multicolumn{7}{|l|}{ Omega 3 mother intake: } \\
\hline No & 25 & 100.0 & 25 & 100.0 & - & - \\
\hline Yes & 0 & 0.0 & 0 & 0.0 & & \\
\hline
\end{tabular}

Table (3): Comparison between the two studied groups a as regard to type of feeding, head support at ${ }^{3}$ month and occurrence of NEC.

\begin{tabular}{|c|c|c|c|c|c|c|}
\hline & \multicolumn{2}{|c|}{$\begin{array}{c}\text { Cases } \\
(\mathrm{n}=25)\end{array}$} & \multicolumn{2}{|c|}{$\begin{array}{l}\text { Control } \\
(\mathrm{n}=25)\end{array}$} & \multirow{2}{*}{$x^{2}$} & \multirow{2}{*}{$p$} \\
\hline & No. & $\%$ & No. & $\%$ & & \\
\hline \multicolumn{7}{|l|}{ Type of feeding: } \\
\hline Breast feeding & 8 & 32.0 & 10 & 40.0 & 0.475 & 0.09 \\
\hline Formula feeding & 0 & 0.0 & 0 & 0.0 & 0.0 & 0.0 \\
\hline Both & 17 & 68.0 & 15 & 60.0 & 0.15 & 0.07 \\
\hline \multicolumn{7}{|c|}{ Head support at ${ }^{3 r d}$ month: } \\
\hline No & 0 & 0.0 & 0 & 0.0 & - & - \\
\hline Yes & 25 & 100.0 & 25 & 100.0 & & \\
\hline \multicolumn{7}{|c|}{$\begin{array}{l}\text { Occurrence of NEC or } \\
\text { feeding intolerance. }\end{array}$} \\
\hline No & 25 & 100.0 & 25 & 100.0 & - & - \\
\hline Yes & 0 & 0.0 & 0 & 0.0 & & \\
\hline
\end{tabular}

Table (4): Comparison between the two studied groups a as regard to initial $\mathrm{CBC}$.

\begin{tabular}{lllll}
\hline $\mathrm{CBC}$ & $\begin{array}{l}\text { Cases } \\
(\mathrm{n}=25)\end{array}$ & $\begin{array}{l}\text { Control } \\
(\mathrm{n}=25)\end{array}$ & $t$ & $p$ \\
\hline$H b(g / d l):$ & & & & \\
$\quad$ Min.-max. & $13.0-23.40$ & $15.0-22.5$ & 0.849 & 0.401 \\
Mean \pm SD. & $16.64 \pm 2.26$ & $17.09 \pm 1.36$ & & \\
Median & 19.0 & 19.0 & & \\
Hct $(\%):$ & & & & \\
Min.-max. & $33.0-70.40$ & $40.60-67.5$ & 1.852 & 0.070 \\
$\quad$ Mean \pm SD. & $47.63 \pm 6.30$ & $50.52 \pm 4.63$ & & \\
Median & 65.0 & 62.0 & & \\
Platelets: & & & & \\
Min.-max. & $100.0-522.0$ & $105.0-320.0$ & 1.435 & 0.160 \\
Mean \pm SD. & $278.88 \pm 91.13$ & $249.40 \pm 47.37$ & & \\
Median & 230.0 & 220.0 & & \\
TLC: & & & & \\
Min.-max. & $4.0-18.0$ & $6.0-16.0$ & $\mathrm{U}=$ & $0.005^{*}$ \\
Mean \pm SD & $9.79 \pm 2.91$ & $8.29 \pm 2.57$ & $167.50^{*}$ & \\
Median & 9.0 & 8.0 & & \\
\hline
\end{tabular}

$t, p \quad: t$ and $p$-values for student $t$-test for comparing between the two groups.

CBC : Complete Blood Count.

$\mathrm{Hb}$ : Haemoglobin.

Hct : Haematocrit.

TLC : Total Leucocytic Count.

Table (5): Comparison between the two studied groups a as regard to CRP initially after birth.

\begin{tabular}{llllllll}
\hline & \multicolumn{2}{c}{$\begin{array}{c}\text { Cases } \\
(\mathrm{n}=25)\end{array}$} & & \multicolumn{2}{c}{$\begin{array}{c}\text { Control } \\
(\mathrm{n}=25)\end{array}$} & $\begin{array}{c}\text { Test } \\
\text { of sig. }\end{array}$ & $p$ \\
\cline { 2 - 3 } & No. & $\%$ & No. & $\%$ & & \\
\hline$C R P:$ & & & & & & & \\
Negative & 25 & 100.0 & 23 & 92.0 & $\chi^{2}=$ & $\mathrm{FE}_{p=}=$ \\
Positive & 0 & 0.0 & 2 & 8.0 & 2.083 & 0.490 \\
\hline
\end{tabular}

$\chi 2, \chi^{2}$ and $p$-values for Chi square test for comparing between the two groups.

$\mathrm{FE}_{p}: p$-value for Fisher Exact for Chi square test for comparing between the two groups.

* : Statistically significant at $p \leq 0.05$ 
Table (6): Comparison between the two studied groups a as regard to CRP after 3 weeks.

\begin{tabular}{|c|c|c|c|c|c|c|}
\hline & \multicolumn{2}{|c|}{$\begin{array}{l}\text { Cases } \\
(\mathrm{n}=25)\end{array}$} & \multicolumn{2}{|c|}{$\begin{array}{c}\text { Control } \\
(\mathrm{n}=25)\end{array}$} & \multirow{2}{*}{$\begin{array}{c}\text { Test } \\
\text { of sig. }\end{array}$} & \multirow{2}{*}{$p$} \\
\hline & No. & $\%$ & No. & $\%$ & & \\
\hline \multicolumn{7}{|l|}{$C R P:$} \\
\hline Negative & 25 & 100.0 & 25 & 100.0 & - & - \\
\hline Positive & 0 & 0.0 & 0 & 0.0 & & \\
\hline
\end{tabular}

$\chi 2, \chi 2$ and $p$-values for Chi square test for comparing between the two groups.

$\mathrm{FE}_{p}: p$-value for Fisher Exact for Chi square test for comparing between the two groups.

* : Statistically significant at $p \leq 0.05$.

Table (7): Comparison between the two studied groups a as regard to renal functions.

\begin{tabular}{|c|c|c|c|c|}
\hline Renal function & $\begin{array}{l}\text { Cases } \\
(\mathrm{n}=25)\end{array}$ & $\begin{array}{l}\text { Control } \\
(\mathrm{n}=25)\end{array}$ & $\mathrm{U}$ & $p$ \\
\hline \multicolumn{5}{|c|}{ Blood Urea $(\mathrm{mg} / \mathrm{dl})$ : } \\
\hline Min.-max. & $10.0-74.0$ & $10.0-39.0$ & 220.0 & 0.072 \\
\hline Mean \pm SD & $25.60 \pm 14.81$ & $25.72 \pm 6.43$ & & \\
\hline Median & 20.0 & 24.0 & & \\
\hline \multicolumn{5}{|c|}{ Creatinine $(m g / d l)$ : } \\
\hline Min.-max. & $0.20-1.10$ & $0.20-1.0$ & 300.00 & 0.803 \\
\hline Mean \pm SD & $0.39 \pm 0.22$ & $0.38 \pm 0.20$ & & \\
\hline Median & 0.30 & 0.30 & & \\
\hline
\end{tabular}

Table (8): Comparison between the two studied groups a as regard to serum electrolytes.

\begin{tabular}{|c|c|c|c|c|}
\hline Electrolytes & $\begin{array}{l}\text { Cases } \\
(\mathrm{n}=25)\end{array}$ & $\begin{array}{l}\text { Control } \\
(\mathrm{n}=25)\end{array}$ & $t$ & $p$ \\
\hline \multicolumn{5}{|l|}{$\begin{array}{l}\text { Serum sodium } \\
(\mathrm{Na}+) \mathrm{mEq} / \mathrm{L} \text { : }\end{array}$} \\
\hline $\begin{array}{l}\text { Min.-max. } \\
\text { Mean } \pm \text { SD. } \\
\text { Median }\end{array}$ & $\begin{array}{l}131.0-145.0 \\
137.04 \pm 2.65 \\
137.0\end{array}$ & $\begin{array}{l}135.0-144.0 \\
138.92 \pm 2.20 \\
138.0\end{array}$ & $2.729 *$ & $0.009^{*}$ \\
\hline \multicolumn{5}{|c|}{$\begin{array}{l}\text { Serum potassium } \\
\left(\mathrm{K}^{+}\right) \mathrm{mEq} / \mathrm{L} \text { : }\end{array}$} \\
\hline $\begin{array}{l}\text { Min.-max. } \\
\text { Mean } \pm \text { SD. } \\
\text { Median }\end{array}$ & $\begin{array}{l}3.0-5.0 \\
3.84 \pm 0.63 \\
3.50\end{array}$ & $\begin{array}{l}3.40-5.40 \\
4.08 \pm 0.69 \\
4.0\end{array}$ & 1.304 & 0.199 \\
\hline \multicolumn{5}{|l|}{$\begin{array}{l}\text { Serum calcium } \\
(\mathrm{Ca}) \mathrm{mg} / \mathrm{dl} \text { : }\end{array}$} \\
\hline $\begin{array}{l}\text { Min.-max. } \\
\text { Mean } \pm \text { SD. } \\
\text { Median }\end{array}$ & $\begin{array}{l}7.70-10.0 \\
8.87 \pm 0.55 \\
9.0\end{array}$ & $\begin{array}{l}7.40-9.70 \\
8.79 \pm 0.45 \\
8.90\end{array}$ & 0.592 & 0.557 \\
\hline
\end{tabular}
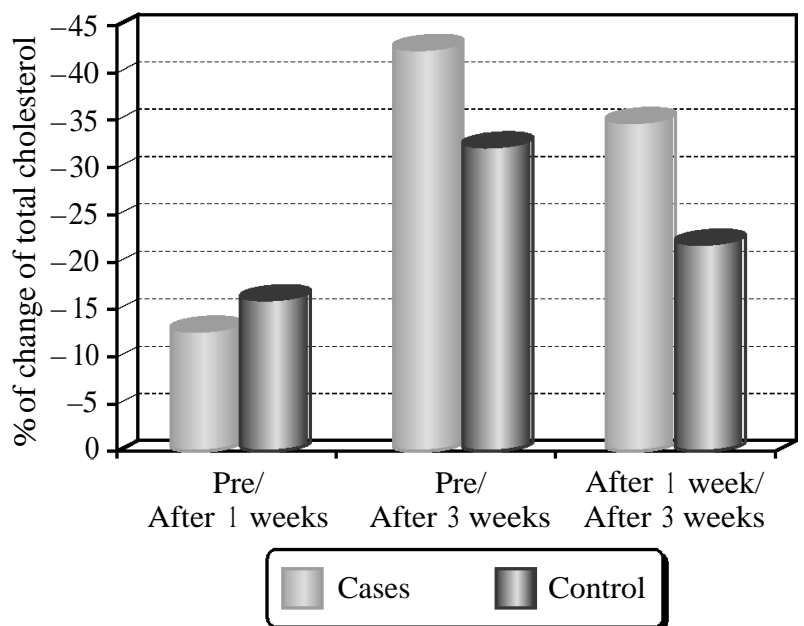

Fig. (5): Comparison between changes in total cholesterol in both studied groups before and after therapy.

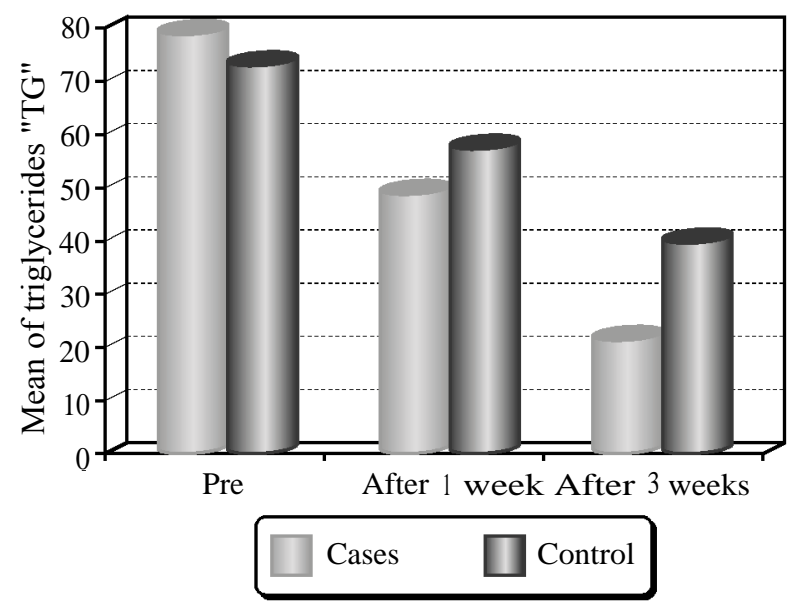

Fig. (6): Comparison between the two studied groups as regard to triglycerides "TG".

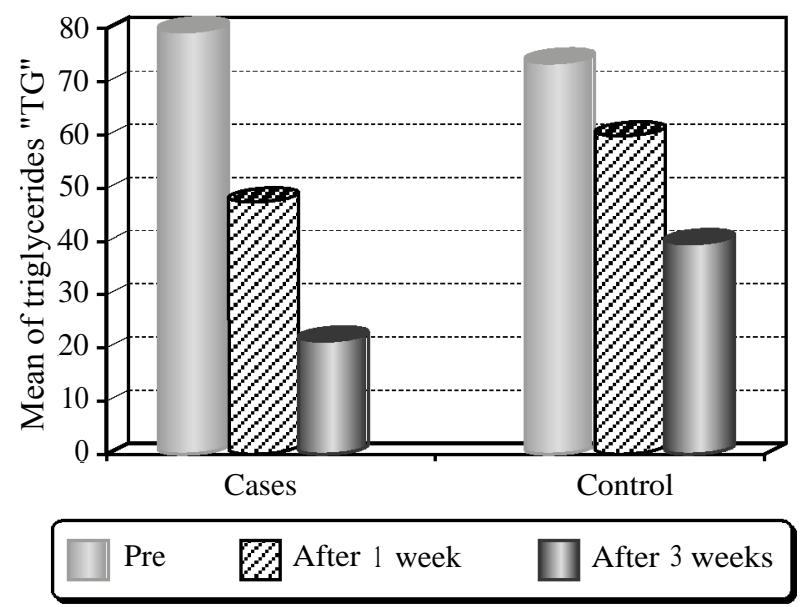

Fig. (7): Comparison between the different studied periods as regard to triglycerides "TG" in each group. 


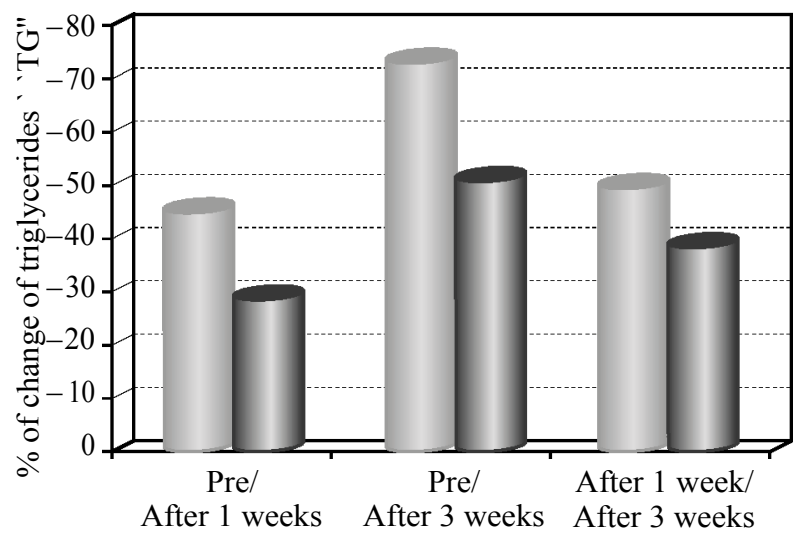

Cases Control

Fig. (8): Comparison between changes of triglycerides in both studied groups before and after therapy.

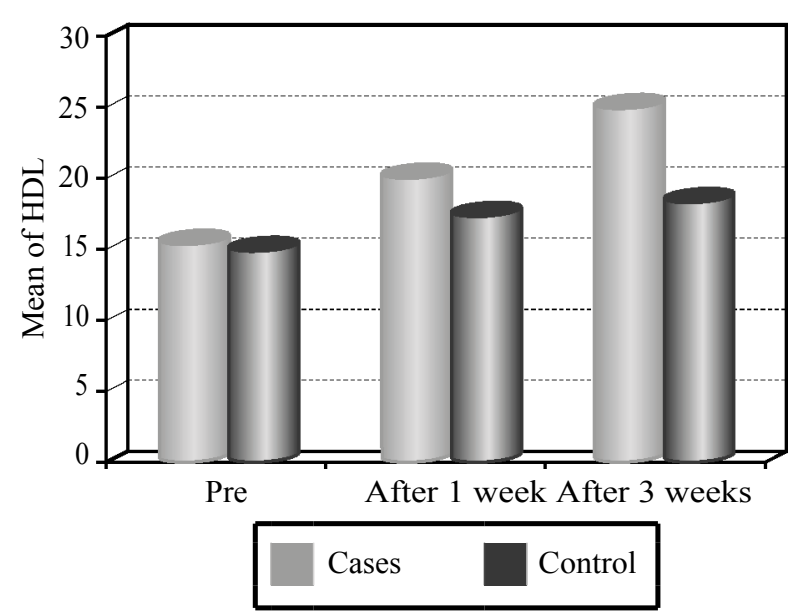

Fig. (9): Comparison between the two studied groups as regard to HDL.

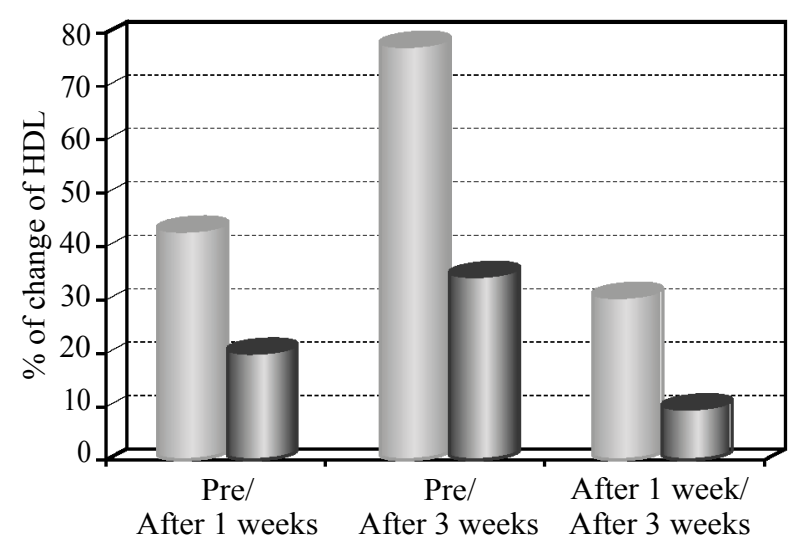

Cases

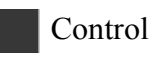

Fig. (10): Comparison between the change of HDL in both groups before and after the therapy.

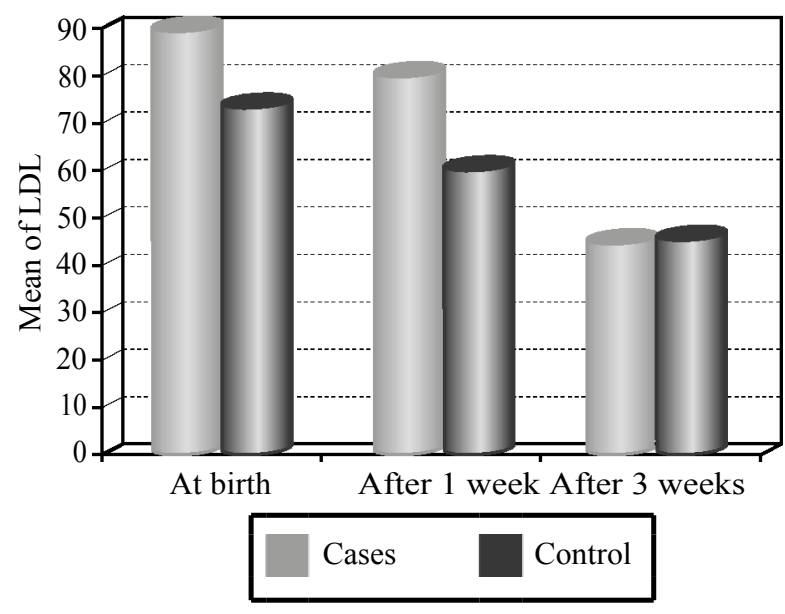

Fig. (11): Comparison between the two studied groups as regard to LDL.

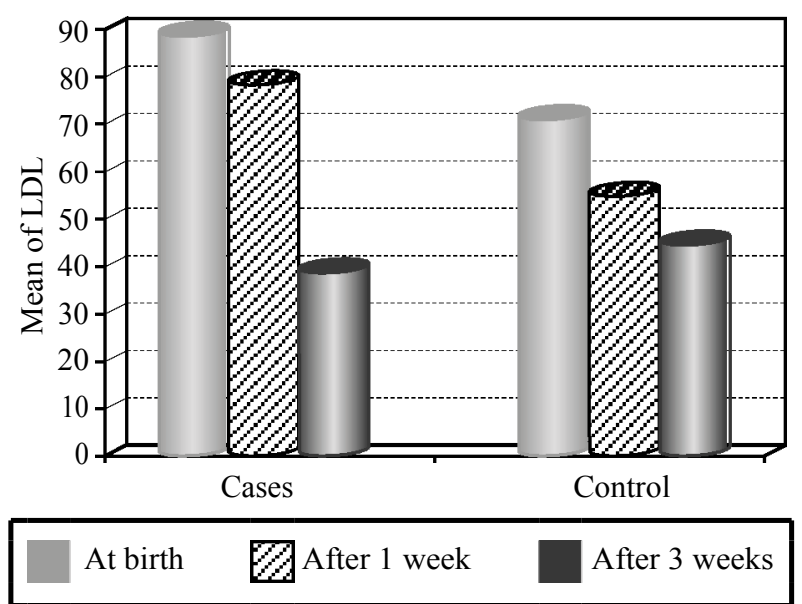

Fig. (12): Comparison between the different studied periods as regard to LDL in each group.

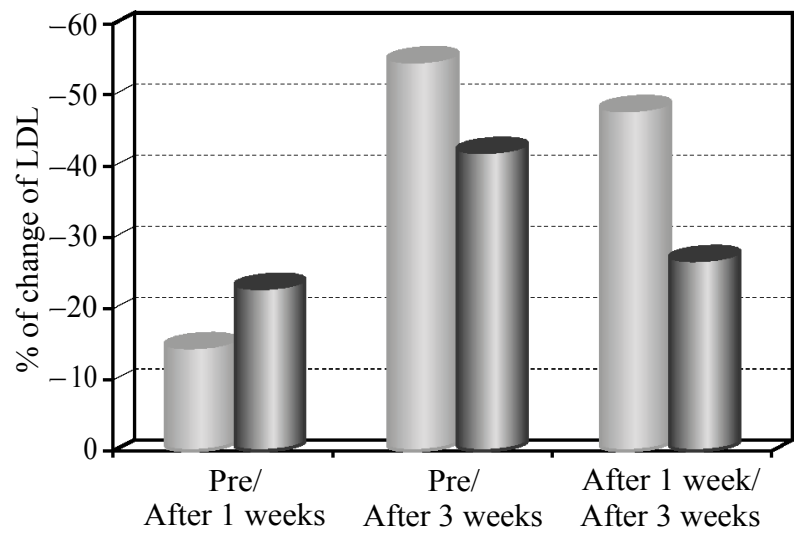

After 1 weeks After 3 weeks After 3 weeks

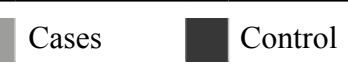

Fig. (13): Comparison between the change of LDL in both groups before and after the therapy. 


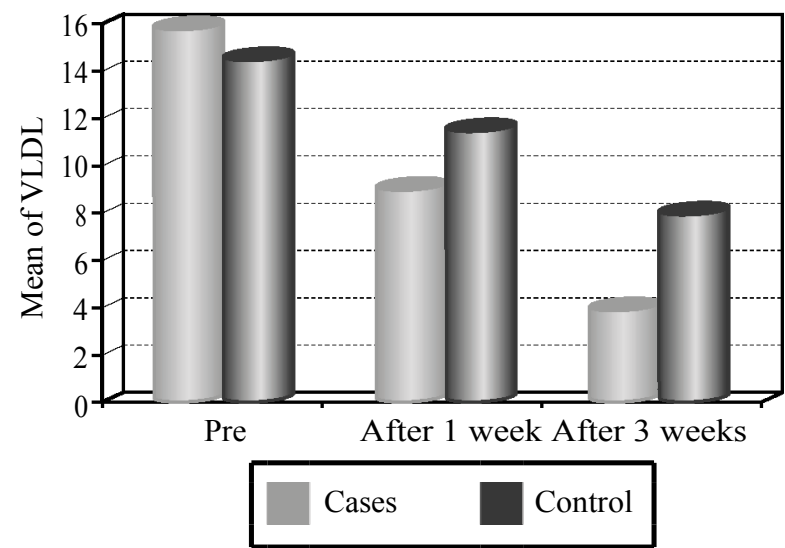

Fig. (14): Comparison between the different studied periods as regard to VLDL in each group.

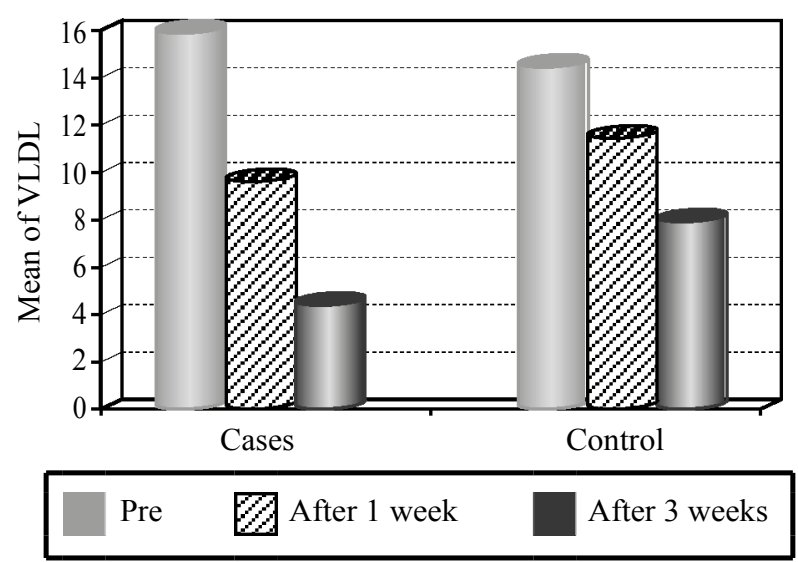

Fig. (15): Comparison between the two studied groups as regard to VLDL.

Table (9): Correlation between weight and lipid profile in each group.

\begin{tabular}{|c|c|c|c|c|}
\hline \multirow{3}{*}{ Lipid profile } & \multicolumn{4}{|c|}{ Weight } \\
\hline & \multicolumn{2}{|c|}{ Cases } & \multicolumn{2}{|c|}{ Control } \\
\hline & $r$ & $p$ & $r$ & $p$ \\
\hline \multicolumn{5}{|l|}{ Total cholesterol: } \\
\hline Pre & 0.060 & 0.776 & 0.341 & 0.096 \\
\hline After 1 week & 0.059 & 0.779 & 0.376 & 0.064 \\
\hline After 3 week & -0.294 & 0.153 & $0.423 *$ & $0.035^{*}$ \\
\hline \multicolumn{5}{|c|}{ Triglycerides " $T G$ ": } \\
\hline Pre & 0.039 & 0.855 & -0.111 & 0.599 \\
\hline After 1 week & 0.132 & 0.528 & -0.032 & 0.878 \\
\hline After 3 week & 0.377 & 0.063 & 0.097 & 0.644 \\
\hline \multicolumn{5}{|l|}{$H D L:$} \\
\hline Pre & 0.170 & 0.416 & 0.196 & 0.349 \\
\hline After 1 week & 0.265 & 0.201 & 0.164 & 0.434 \\
\hline After 3 week & 0.151 & 0.472 & 0.075 & 0.721 \\
\hline \multicolumn{5}{|l|}{$L D L:$} \\
\hline Pre & 0.026 & 0.901 & -0.174 & 0.406 \\
\hline After 1 week & -0.028 & 0.895 & -0.266 & 0.199 \\
\hline After 3 week & $-0.404 *$ & $0.045^{*}$ & -0.010 & 0.961 \\
\hline \multicolumn{5}{|l|}{$V L D L:$} \\
\hline Pre & 0.038 & 0.856 & -0.110 & 0.600 \\
\hline After 1 week & 0.133 & 0.526 & -0.034 & 0.872 \\
\hline After 3 week & 0.376 & 0.064 & 0.096 & 0.647 \\
\hline
\end{tabular}

\section{Discussion}

Intrauterine Growth Restriction (IUGR) refers to a condition in which a fetus is unable to achieve its genetically determined potential size. This functional definition seeks to identify a population of fetuses at risk for modifiable but otherwise poor outcomes. This definition intentionally excludes fetuses that are Small for Gestational Age (SGA) but are not pathologically small [1].

Omega-3 fatty acids are one of two classes of essential fatty acids. Linoleic acid is converted to Arachidonic Acid (AA) and a-linolenic acid to Docosahexaenoic Acid (DHA) and Eicosapentaenoic Acid (EPA). Particularly AA and DHA accumulate rapidly during the last trimester and the first postnatal months which is the period of rapid growth and brain development [12] .

As regard demographic data of the current study, there was no significant differences between both groups in birth weight and weight after 1 week with $p$-values respectively $(0.742,0.510)$, but after 3 weeks there was significant increase in weight in control group in comparison to cases group with $p=0.004$. This came in agreement with Bouwstra et al., 2005 who found no statistically difference between LCPUFA and control groups at 6 months of age of full term healthy neonates [13]. Birch et al., 2010 reported that there were no significant effects on weight of control or LCPUFA groups at 1.5 months. But the weight of the supplemented group was significantly lower than the other group at 4, 6, 9 months of age [14]. In contrast to the current study Collins et al., 2011 supplemented DHA in 2 different doses to premature infants less than $1250 \mathrm{~g}$ and more than $1250 \mathrm{~g}$, they concluded that the infants with birth weight less than $1250 \mathrm{~g}$ had no significant difference with higher doses of DHA. While infants with birth weight more than $1250 \mathrm{~g}$ had significant increase in weight at 12 months of age. They attributed this lack of increment of birth weight that those babies with birth weight less than $1250 \mathrm{~g}$ were sicker than the babies with birth weight more than $1250 \mathrm{~g}$ [15]

As regard length in the current study, there was no significant difference in both groups in all times of measurement (initially at birth, after 1 week and after 3 weeks) with $p=0.156,0.172,0.146$ respectively. This came in agreement with Austed, 2001 who found in his study which was done on 239 full term neonates ( 72 fed formula with DHA + A.A and 165 were breast fed) that the supplemented group had the same length at 4 months in comparison to control group [16]. Birch et al., 2010 reported 
that there were no significant effects of supplemented group on length at 1.5, 6, 9, and 12 months [14] . But in contrast to current study, Collins et al., 2011 reported in a randomized controlled trial on 657 preterm neonates that there was increase in the length of the higher DHA group $0.7 \mathrm{~cm}$ greater than the standard DHA group at 18 months [15]

As regard head circumference in the current study, there was no significant difference in head circumference between both groups in all times of measurements (at birth, after 1 week, after 3 weeks). While during the comparison within the same group, there was significant increase in head circumference. In contrast to the current study Deng et al., 2012 meta-analysis of the effect of Omega 3 supplementation of pregnant women on head circumference of newborn, reported that 871 cases group had greater head circumference in comparison to 894 placebo group [17]. Also Collins et al., 2011 who supplemented DHA in 2 different doses to premature infants less than $1250 \mathrm{~g}$ and they reported that the supplemented group with high DHA had greater head circumference than standard control group at 12 weeks of age [15].

As regard mode of delivery in the current study, there was increase in number of cases delivered by cesarean section (38 cases) as compared to cases delivered by normal vaginal delivery (12 cases), but with no significance. This came in agreement with Gaudineau, 2013 who reported in his study that there were high rates of cesarean section delivery in IUGR neonates [18]

As regard risk factors for IUGR in current study, there was 17 mothers who have gestational hypertension, 7 mothers have anemia, 2 mothers have anemia, HTN and D.M, but with no significance. This came in agreement with Gaudineau, 2013 who studied the risk factors for IUGR in his study and reported that there was increase in rate of IUGR 4 fold in mothers with previous history of pregnancy with SGA 5-12 fold in mothers with pre-eclampsia, 5 fold in mother with DM and vascular diseases [18]. Also the current study coincide with Wang et al., 2017 who studied 337 LBW and they revealed that there was increased risk for IUGR neonates in mothers with HTN with $p=0.001$ [19].

As regard CBC changes in the current study, there were no significant difference between both groups as regard $\mathrm{Hb}$, Hct and platelets levels. Some cases showed polycythemia (haematocrit level more than 65\%). This result was in agreement with Shikha et al., 2008, they studied 50 infants, 30 of them was AGA infants and 20 infants was IUGR and they reported that the incidence of polycythemia was higher in those infants that experienced chronic intrauterine hypoxia that in turn resulted in increased fetal erythropoiesis [20] Another study done by Kush et al., 2006 where they studied 73 neonates, 38 with IUGR and 35 AGA infants and they reported $45 \%$ of IUGR infants subjected to polycythemia and they reported that the hematologic alterations is dependent on the severity of placental insufficiency [21].

In the current study thrombocytopenia was detected in some cases and that came in agreement with previous studies. In a study done by Mouna et al., 2017 on 120 pre-eclamptic mothers and their babies, the most significant feature found in this study was the presence of thrombocytopenia in the babies born to pre-eclamptic mothers and it was $94-250 / \mathrm{cmm}$ when compared to babies of normotensive mothers with $p<0.001$ [22].

As regard CRP there was no significant difference between both groups initially and after 3 weeks. This came in agreement with Garaiova et al., 2013 study which was done on 25 participants with mean age 16 years who received fish oil for 16 weeks with no significant changes in CRP [23]

As regard lipid profile level: In the current study there was non-significant increase in level of Total Cholesterol (TC) in cases and control groups. While within the same group there was significant decrease of total cholesterol after 1 and 3 weeks. The decreasing level of T.C after 1 and 3 weeks of age in both groups may be related to the immaturity of neonatal liver and its enzymes are not well developed for lipid metabolism and so can contribute to lower values in lipid profile. This came in agreement with Aletayeb et al., 2013 who studied 203 cases divided into 3 groups, group 1 was LBW with birth weight below $2500 \mathrm{~g}$, group 2 was AGA with birth weight 2500-4000g and group 3 was LGA with high birth weight more than $4000 \mathrm{~g}$. They reported that the serum levels of total cholesterol was higher in Group 1 and 3 than group 2 with $(p<0.05)$ [24]. Piyush et al., 2012 reported in their study which was conducted on 3 groups. Group 1 was normal newborn (35), group 2 was normal infant (50) and Group 3 was LBW newborn (35) that the levels of total cholesterol were higher in Group 2, 3 than Group 1 with $(p$ $<0.0001$ ) [29]

As regard rate of decrement of high levels of total cholesterol in the current study there was significant decrement rate after 2 weeks of supple- 
mentation with Omega 3 by $42.75 \%$ in cases group which was more than the decrement in control group which was $26.6 \%$. To the best of our knowledge no previous studies were done on the effect of supplementation of Omega 3 on the lipid profile levels in neonates with FGR. But there were many studies on that issue in adults and we will compare the results of the current study with these studies. The current study came in agreement with James et al., 2007 who conducted their study on 42 adult suffering from severe hypercholesterolemia patients after giving them Omega 3 for 16 weeks and measuring lipid profile after period of treatment, they found that there was decline in total cholesterol level by $20 \%$ more in cases group than the other group who received placebo treatment [25]. But in contrast to current study, Chen et al., 2015 metaanalysis which was carried out on 17 RCTs on type 2 D.M adult patients (906 participants) who received Omega 3 for at least 2 weeks and placebo patients who received vegetable oil. They found that there was no significant decrease in level of total cholesterol after supplementation of Omega 3 [26].

In current study there was non-significant increase in level of Triglycerides (TG) in both cases and control groups at birth with mean $77.87 \pm 42.59$ and $70.51 \pm 29.74$ respectively. While there was significant decrease of triglycerides after 3 weeks in cases group than control group with $p=0.02$. This came in agreement with Aletayeb et al., 2013 who studied 203 cases divided into 3 groups, Group 1 was LBW with birth weight below $2500 \mathrm{~g}$, Group 2 was AGA with birth weight 2500-4000g and Group 3 was LGA with high birth weight more than $4000 \mathrm{~g}$. They reported that the serum levels of triglycerides were higher in Group 1 and 3 than Group 2 with $(p<0.05)$ [24]. These changes may be attributed to the maturity of pregnancy and also the nutritional status of the fetus [27]. The increased level of TG could be due to reduced insulin level in fetal plasma and lower insulin dependent activation of lipoprotein lipase so hampering efficient lipolysis of triglyceride. Thus insulin and its effect on lipid metabolism could play a major role in intrauterine growth [28]. Piyush et al., 2012 reported in their study which was conducted on 3 groups. Group 1 was normal newborn (35), Group 2 was normal infant (50) and Group 3 was LBW newborn (35) that all levels of TG were higher in Group 2, 3 than Group 1 [29].

In the current study as regard rate of decrement of high levels of T.G there was significant decrement rate after 2 weeks of supplementation with Omega 3 by $79.96 \%$ in cases group that was more than the decrement in control group which was $51.13 \%$. The current study results came in agreement with Dean, 2017 who reported in his double blinded placebo controlled study on 42 patients that patients who received Omega 3 have lower levels of TG than placebo group [30]. Also, Chauhan et al., 2017 study coincide with the results of the current study in his prospective single blind randomized trial which was done on 100 patients with the result of decreasing TG levels after consumption of Omega 3 (1 $\mathrm{gm}$ twice daily) [31]. Also it came with agreement with Cai et al., 2015 meta-analysis which was carried out on 17 RCTs on type 2 D.M patients who received Omega 3 for at least 2 weeks and placebo patients who received vegetable oil. They found that there was decrease in level of triglycerides after supplementation of Omega 3 [32]

Current study came in agreement with James et al., 2007 who studied 42 patients after giving them Omega 3 for 16 weeks and measuring lipid profile after period of treatment, they found that there was decline in triglycerides level by $45 \%$ more in cases group than the other group who received placebo treatment [25]. But in contrast to current study Magdalena et al., 2017 found in there study which was conducted on 30 patients with (hypertriglyceridemia after myocardial infarction) after supplementing them with $1 \mathrm{gm}$ daily of EPA and DHA and another placebo group who received $1 \mathrm{gm}$ daily of corn oil, they demonstrated that there was no effect of Omega 3 supplementation after 12 weeks of treatment on serum levels of lipid profile including triglycerides [33]

In the current study there was non-significant decrease in level of HDL in both cases and control groups at birth with mean $14.53+4.05$ and $14.08+$ 4.33 respectively. While there was significant increase of HDL after 1 and 3 weeks which was higher in cases group than control group with $p=0.03,0.004$ respectively. This came in agreement with Piyush et al., 2012 who reported in their study which was conducted on 3 groups, Group 1 was normal newborn (35), Group 2 was normal infant (50) and Group 3 was LBW newborn (35), that all levels of TC, TG, LDL VLDL except HDL were higher in Group 2, 3 than Group 1. The fall of HDL was associated with increased activity of Lethicin Cholesterol Acyl Transferase Enzyme (LCATE) [29]. Spear et al., 1991 demonstrated that LCATE activity was lower in near term neonates compared with the term infants [34]

In the current study as regard rate of increment of low levels of HDL there was significant incre- 
ment rate after 2 weeks of supplementation Omega 3 by $62.5 \%$ in cases group which was more than the increament in control group which was $20 \%$. The results of the current study came in agreement with James et al., 2007 who studied 42 patients after giving them Omega 3 for 16 weeks and measured lipid profile after period of treatment, they found that there was increase in HDL level by $13 \%$ more in cases group than the other group who received placebo treatment [25]. In contrast to current study Magdalena et al., 2017 found in there study which was conducted on 30 patients with (hypertriglyceridemia after myocardial infarction) after supplementing them with $1 \mathrm{gm}$ daily of EPA and DHA and another placebo group who received $1 \mathrm{gm}$ daily of corn oil, they demonstrated that there was no effect of Omega 3 supplementation after 12 weeks of treatment on serum levels of lipid profile including HDL levels [33]

In current study there was significant increase in level of LDL in cases and control groups at birth with mean $88.32+29.04$ and $70.38 \pm 23.92$ respectively. Also there was significant decrease of LDL after 1 week in cases group more than control group with $p<0.001$. While there was no significant decrease after 3 weeks with $p=0.79$. This came in agreement with Aletayeb et al., 2013 who researched on 203 cases divided into 3 groups, Group 1 was LBW with birth weight below $2500 \mathrm{~g}$, Group 2 was AGA with birth weight $2500-4000 \mathrm{~g}$ and Group 3 was LGA with high birth weight more than $4000 \mathrm{~g}$. They reported that the serum levels of LDL were higher in Group 1 and 3 than Group 2 with $(p<0.05)$ [24]. Piyush et al., 2012 who reported in their study which conducted on 3 groups, Group 1 was normal newborn (35), Group 2 was normal infant (50) and Group 3 was LBW newborn (35), that all levels of LDL were higher in Group 2, 3 than Group 1 [29]

In the current study as regard rate of decrement of high levels of LDL there was significant decrement rate after 2 weeks of supplementation withOmega 3 by $55.84 \%$ in cases group which was more than the decrement in control group which was $31.34 \%$. The results of the current study came in agreement with Garaiova et al., 2013 who reported in their study which was done on 25 participants with mean age 16 years and who received a daily supplementation of fish oil for 16 weeks, that there was significant decrease in levels of LDL with $(p<0.05)$. In the current study there was non-significant increase in level of VLDL in cases and control groups at birth with mean $15.57+8.51$ and $14.08+5.94$ respectively. While there was significant decrease of VLDL after 3 weeks in cases group than control one with $p=0.02$. This came in agreement with Aletayeb et al., 2013 who researched on 203 cases divided into 3 groups, Group 1 was LBW with birth weight below $2500 \mathrm{~g}$, Group 2 was AGA with birth weight 2500-4000g and Group 3 was LGA with high birth weight more than $4000 \mathrm{~g}$. They reported that the serum levels of VLDL were higher in Group 1 and 3 than Group 2 with $(p<0.05)$ [24] . Piyush et al., 2012 who reported in their study which was conducted on 3 groups, Group 1 was normal newborn (35), Group 2 was normal infant (50) and Group 3 was LBW newborn (35), that all levels of VLDL were higher in Group 2, 3 than Group 1 [29]

In the current study as regard rate of decrement of high levels of VLDL there was significant decrement rate after 2 weeks of supplementation witOmegaga 3 by $80.08 \%$ in cases group which was more than the decrement in control group which was $51.3 \%$. The results of the current study came in agreement with Garaiova et al., 2013 who reported in their study which was done on 25 participants with mean age 16 years who received a daily supplementation of fish oil for 16 weeks, that there was significant decrease in levels of LDL with $(p<0.05)$ [23]. Also this came in agreement with Dallongeville et al., 1991 who reported in their study which was done on adult patients suffering from type 3 dys-beta-lipoproteinemia and who received 6 grams of Omega 3 for 12 weeks, there was significant decrease in levels of VLDL [35] Garaiova et al., 2013 suggested that Omega 3 fatty acids reduce the synthesis and secretion of VLDL particles and increase TG removal from VLDL and chylomicron particles through the up-regulation of enzymes such as lipoprotein lipase [23]. Dallongeville et al., 1991 suggested that fish oils can reduce VLDL and chylomicron remnant concentrations by several mechanisms. First they reduce triglyceride synthesis and VLDL production. Because VLDL and chylomicrons share the same lipolytic pathway, a significant decrease in VLDL mass may favor lipolysis of chylomicrons and therefore their uptake. Fish oils may also modify VLDL or chylomicron lipid compositions in such a way that they become a better substrate for lipoprotein lipase or liver receptor-mediated uptake there by increasing their catabolism [35]. In contrast to the current study Magdalena et al., 2017 found in their study which was conducted on 30 patients with (hypertriglyceridemia after myocardial infarction) after supplementing them with $1 \mathrm{gm}$ daily of EPA and DHA and another placebo group who received $1 \mathrm{gm}$ daily of corn oil, they demonstrated that there was no effect of Omega 3 supplementa- 
tion after 12 weeks of treatment on serum levels of lipid profile including VLDL levels [33].

The current study found that there was significant negative correlation between weight after 3 weeks and level of LDL after 3 weeks in cases group with $p=0.045$. In contrast to the current study Chandika et al., 2013 reported a statistically significant positive correlation between LDL level and birth weight with $p=0.042$. Also there was moderate positive correlation, which may be due to sample number, between weight after 3 weeks and level of TG after 3 weeks in cases group with $p=0.063$. There was moderate negative correlation between weight after 3 weeks and level of VLDL in cases group after 3 weeks with $p=0.064$. There was lack of correlation between birth weight and TC level in cases group while there was significant positive correlation between TC level and weight after 3 weeks with $p=0.035$ in control group [36].

In our study there was no significant correlation between birth weight and HDL level in both cases and control group. This came in agreement with Chandika et al., 2013 as they reported that HDL levels showed no significant correlation with the anthropometric data [36]

Larger scale study is recommended for approval of the efficacy and safety Omega 3 use in IUGR neonates for controlling the serum lipid profile.

\section{Conclusion and Recommendations:}

There was significant increase in level of LDL in cases and control groups. There was significant decrease of LDL after 1 week in cases group more than control group. As regard rate of decrement of high levels of LDL there was significant decrement rate after 2 weeks of supplementation with Omega 3 by $55.84 \%$ in cases group which was more than the decrement in control group which was $31.34 \%$. Also, there was an increase in level of TC initially in IUGR neonates and this level was decreased after supplementation of Omega 3 for 2 weeks. There was a decrease in level of HDL initially in IUGR neonates and this level was significantly increased after supplementation of Omega 3 for 2 weeks. There was an increase in level of LDL initially in IUGR neonates and this level was decreased after supplementation of Omega 3 for 2 weeks. There was an increase in level of VLDL initially in IUGR neonates and this level was significantly decreased after supplementation of Omega 3 for 2 weeks.

Omega 3 could be safe in IUGR neonates for controlling the serum lipid profile. Screening for lipid profile is important to be done in all IUGR neonates at birth and during follow-up. Larger scale study including (full term and preterm IUGR neonates) for determination of lipid profile in different age groups and long term follow-up is recommended for all IUGR neonates for detection of CVD and the effect of Omega 3 on these groups.

\section{References}

1- JAISWAL N., KHARATMAL J. and RATNAPARKHI K.: Intrauterine growth retardation (IUGR). National Journal of Research in Ayurved Science, 3 (2): 1-7, 2015.

2- MANNING F.A.: General principles and applications of ultrasonography. Maternal-fetal medicine: Principles and practice. Philadelphia: Saunders; 2004.

3- EL-BAZ M., EL-DEEB T.S., EL-NOWEIHI A.M., MOHANY K.M., SHAABAN O.M., et al.: Environmental factors and apoptotic indices in patients with intrauterine growth retardation: Nested case-control study. Science Direct., 39 (2): 589-96, 2015.

4- OKEN E.: Maternal and child obesity: The causal link Obstet. Gynecol. Clin. North Am., 36: 361-77, 2009.

5- HELLAND I.B., SMITH L., SAAREM K., SAUGSTAD O.D. and DREVON C.A.: Maternal supplementation with very-long chain $n-3$ fatty acids during pregnancy and lactation augments children's IQ at 4 years of age," Pediatrics, 111 (1): 39-44, 2003.

6- AGOSTONI C.: "Docosahexaenoic acid (DHA): From the maternal-foetal dyad to the complementary feeding period," Early Human Development, 86 (1): 3-6, 2010.

7- BALLARD J.L., KHOURY J.C. and WEDIG K.: New Ballard score, expanded to include extremely premature infants. J. Pediatr., 119 (3): 417-23, 1991.

8- KOLETZKO B., POINDEXTER B. and UAUY R.: Nutritional care of preterm infants: Scientific basis and practical guidelines. World Rev. Nutr. Diet. Basel, Karger, 110: 307-14, 2014.

9- NIGAM P.K.: Serum Lipid Profile: Fasting or Non-fasting? Ind. J. Clin. Biochem., 26 (1): 96-7, 2011.

10- NARAYANA S.: Pre and post analytical errors in lipid determination. Indian J. Clin. Biochem., 11: 12-6, 1996.

11- FRIEDEWALD W., LEVY R. and FREDRICKSON D.: Estimation of the concentration of low-density lipoprotein cholesterol in plasma, without use of the preparative ultracentrifuge. Clin. Chem., 18: 499-502, 1972.

12- OH R.: Practical applications of fish oil (Omega-3 fatty acids) in primary care. J. Am. Board. Fam. Pract., 18: 2836, 2005.

13- BOUWSTRA H., DIJCK-BROUWER D.A., BOEHM G., BOERSMA E.R., MUSKIET F.A., et al.: Long-chain polyunsaturated fatty acids and neurological developmental outcome at 18 months in healthy term infants. Acta Paediatrica, 9 (1): 26-32, 2005.

14- BIRCH E.E., CARLSON S.E., HOFFMAN D.R., FITZGERALD-GUSTAFSON K.M., FU V.L., et al.: The DIAMOND (DHA Intake and Measurement of Neural Development) Study a double-masked, randomized controlled clinical trial of the maturation of infant visual 
acuity as a function of the dietary level of docosa-hexaenoic acid. American Journal of Clinical Nutrition, 91 (4): 848-59, 2010.

15-COLLINS C.T., MAKRIDES M., GIBSON R.A., McPHEE A.J., DAVIS P.G., et al.: Pre-and post-term growth in pre-term infants supplemented with higher-dose DHA: A randomized controlled trial. British Journal of Nutrition, (105): 1635-43, 2011.

16- AUESTAD N., HALTER R., HALL R.T., BLATTER M., BOGLE M.L., et al.: Growth and development in term infants fed long-chain polyunsaturated fatty acids: A double-masked randomized, parallel, prospective, multivariate study, Pediatrics, 108 (2): 372-81, 2001.

17- DENG J., XIEL, LIU G.L. and YANG J.Y.: Meta-analysis of the effect of Omega 3 supplementation of pregnant women on head circumference newborns. Chinese Journal of Preventive Medicine, 46 (12): 1112-6, 2012.

18- GAUDINEAU A.: Prevalence, risk factors, maternal and fetal morbidity and mortality of intrauterine growth restriction and small-for-gestational age. Journal de gynecologie, obstetrique et biologie de la reproduction, Dec., 42 (8): 895-910, 2013.

19- WANG J., ZENG Y., WANG J., LI C., WANG Q., et al.: Risk factors for low birth weight and preterm birth: A population-based case-control study in Wuhan, China. Journal of Huazhong University of Science and Technology, 37: (2): 286-92, 2017.

20- SHIKHA S. and TED S.R.: Neonatal polycythemia and hyperviscosity, Elsevier. Seminars in Fetal and Neonatal medicine, (13): 248-55, 2008.

21- KUSH M.L., GORTNER L., HARMAN C.R. and BASCHAT A.A.: Sustained hematological consequences in the first week of neonatal life secondary to placental dysfunction. Early Hum. Dev., (1): 67-72, 2006.

22- MOUNA K., DODDGOWDA S.M. and JUNJEGOWDA K.: Changes in Haematological Parameters in Newborns Born to Preeclamptic Mothers-A Case Control Study in a Rural Hospital. Journal of Clinical and Diagnostic Research, 11 (7): 26-9, 2017.

23- GARAIOVA I., MUCHOVA J., NAGYOVA Z., MISLANOVA C., ORAVEC S., et al.: Effect of plant sterol, fish oil and B vitamin combination on cardiovascular risk factors in hypercholesterolemic children and adolescents: A pilot study. Nutrition Journal, 12 (7): 1-8, 2013.

24- ALETAYEB S.M., DEHDASHTIAN M., AMINZADEH M., MOGHADDAM A.E., MORTAZAVI M., et al.: Correlation between umbilical cord blood lipid profile and neonatal birth weight. Polish Pediatric Society, (88): 521-5, 2013.
25- JAMES M.M. and DOMENIC S.: Prescription of Omega 3 fatty acids for the treatment of hypertriglyceridemia. Am. J. Health-Syst. Pharm., 64: 595-605, 2007.

26- CHEN C., YU X. and SHAO S.: Effects of Omega 3 fatty acids supplementation on glucose control and lipid levels in type 2 Diabetes: Meta-Analysis, 10 (10): 1-14, 2015.

27- GUNES T., KOKLU E. and OZTURK M.A.: Maternal and cord serum lipid profiles of preterm infants with respiratory distress syndrome. J. Perinatol., 27 (7): 41521, 2007.

28- HUTER O., BREZINKA C., DREXEL H. and PATSCH J.R.: Cord blood lipids and lipoproteins in small-, appropriate-, and large-for-gestational age neonates born to non-diabetic mothers. J. Matern. Fetal. Invest., 7: 172-4, 1997.

29- PIYUSH B.T., SHAILESH M.P., CHINMAY J.S. and NIHARIKA U.: Establishment of reference range for lipid profile in healthy newborn, infant and low birth weight newborn in Indian population, 1 (4): 34-6, 2012.

30- DEAN G.K.: A review of clinical practice guidelines for the management of hypertriglyceridemia: A focus on high dose omega 3 fatty acids. Adv. Ther., 34: 300-23, 2017.

31- CHAUHAN S., KODALI H., NOOR J., RAMTEKE K. and GAWAI V.: Role of Omega 3 fatty acids on lipid profile in diabetic dyslipidemia: Single blind, randomized clinical trial. Journal of Clinical and Diagnostic Research, 11 (3): 13-6, 2017.

32- CAI C., XUEFENG Y. and SHIYING S.: Meta-analysis about effect of Omega 3 supplementation on glucose and lipid level in type 2 DM.US National Library of Medicine, (10): 1371-95, 2015.

33- MAGDALENA M., PAROL G., PARZONKO A. and KOZLOWSKA-WOJCIECHOWSKA M.: Supplementation with Omega-3 acids after myocardial infarction and modification of inflammatory markers in light of the patients' diet: A preliminary study. Kardiologia Polska (Polish Heart Journal), 75 (7): 674-81, 2017.

34- SPEAR M.L., AMR S., HAMOS M., PEREIRA G.R., CORCORAN L.G., et al.: Lecithin cholesterol acyl transferase activity during lipid infusion in premature infants. Journal of Pediatric Gastroenterology and Nutrition, 13: 72-6, 1991.

35- DALLONGEVILLE J., BOULT L., DAVIGNON J. and LUSSIER C.S.: Fish oil supplementation reduces VLDL in type III Dys-betalipoproteinemia, 11 (4): 865-71, 1991.

36- CHANDIKA D.N., VAIBHAV A. and DINESH M.N.: Correlation of cord blood lipid heteroginicity in neonates with their anthropometry at birth. Ind. J. Clin. Biochem., 28 (2): 152-7, 2013. 


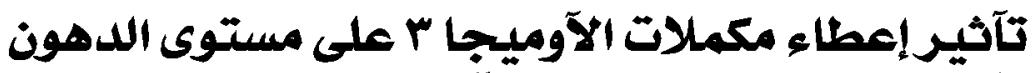

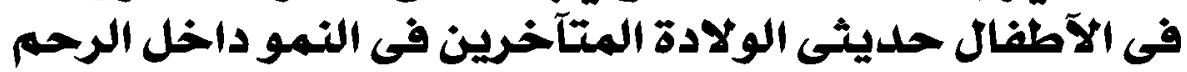

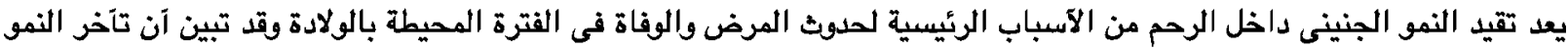

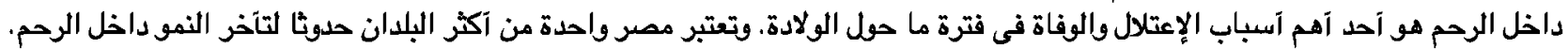

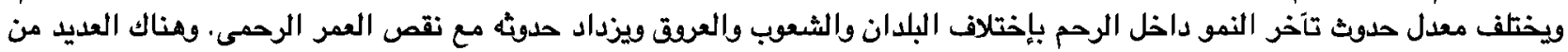

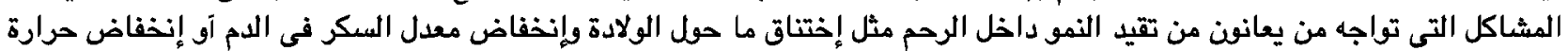

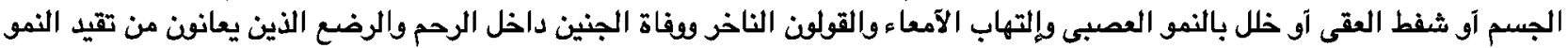

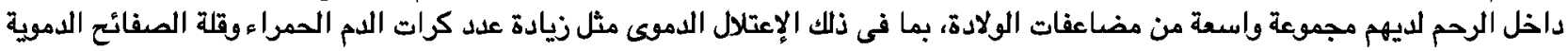

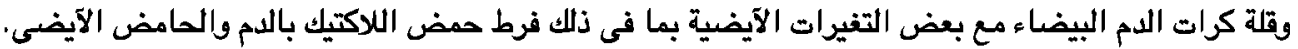

في آواخر عام .191 نشرت العديد من الآبحاث العلمية التى تربط بين الآطفال الذين يعانون من تآخر النمو داخل الرحم وإرتباط ذلك فيما

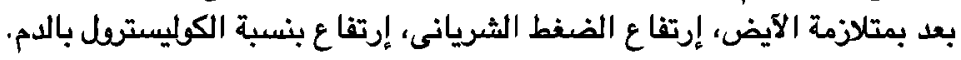

آجريت الدراسة على •0 طفل حديثى ولادة كامل النمو ومتآخرين فى النمو داخل الرحم خلال فترة سنة واحدة في مستشثفيات جامعة طنطا

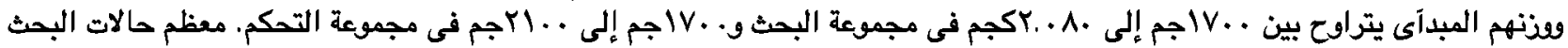

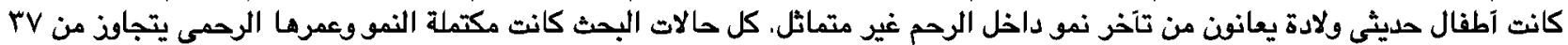

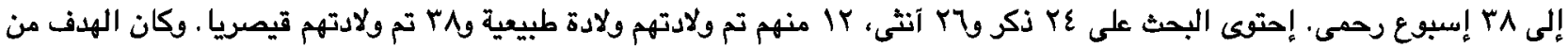

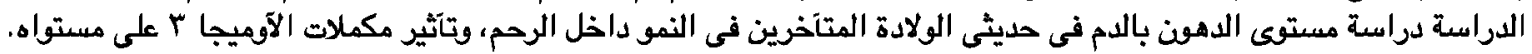

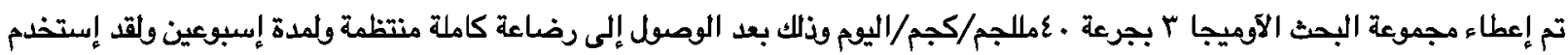

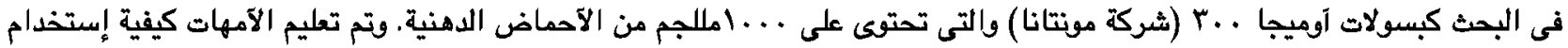

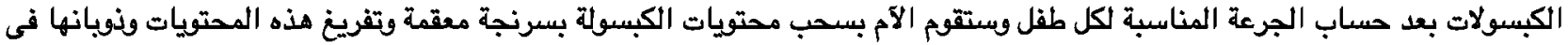

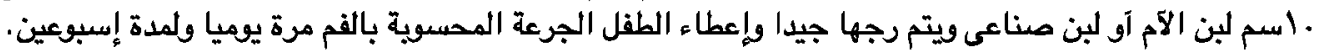

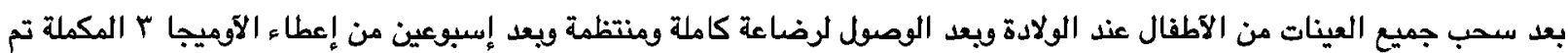

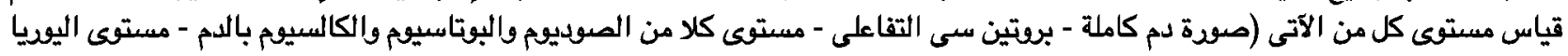

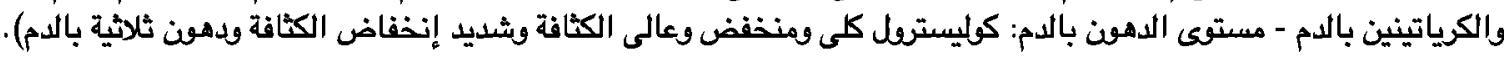

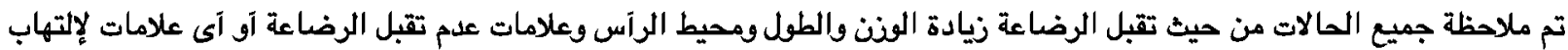
الآمعاء. وكل هذه الييانات يتم عمل تناسب بينها وبين نسب الدهون فى مختلف الفترات العمرية فى مجموعتى البحث.

تم عمل الإحصاء الطبى بالطرق العلمية المعهوده (إختيار ستيودنت تى وعلاقة بيرسن).

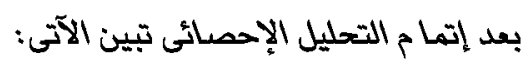

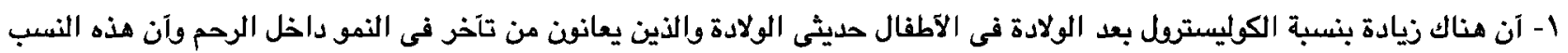

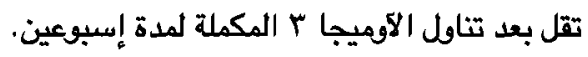

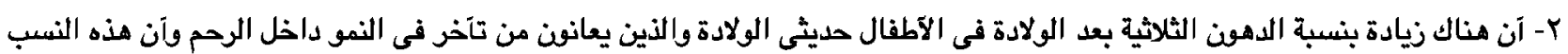
تقل بعد تناول الأوميجا ب الكملة لمدة إسبوعين.

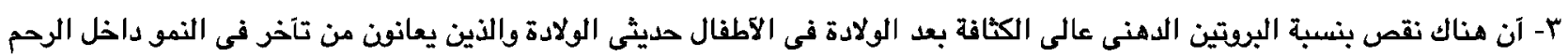
قآن هذه النسب تزيد بعد تتاول الأوميجا ب المكملة لمدة إسبوعين.

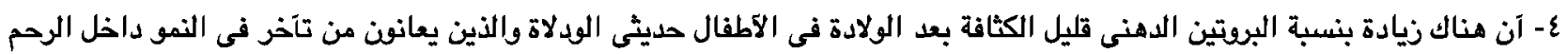

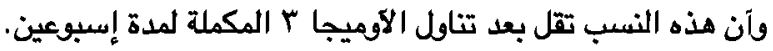

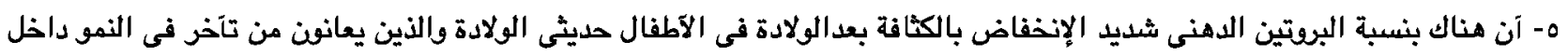
الرحم وآن هذه النسب تقل بعد تتاول الآوميجا ب المكملة بعد إسبوعين.

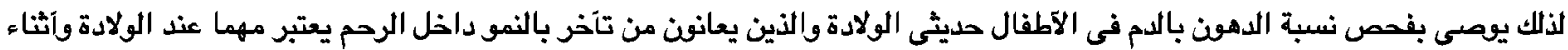

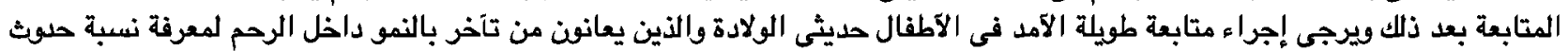

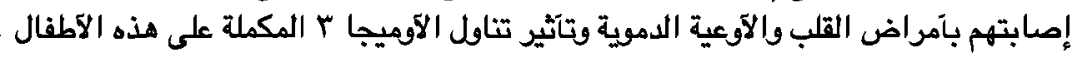

